\title{
Physicochemical and Biochemical Reclamation of Soil through Secondary Succession
}

\author{
Kamala Haripal, Sunanda Sahoo \\ Ecology Section, School of Life Sciences, Sambalpur University, Burla, India. \\ Email: drsunsnda_sahoo@yahoo.com
}

Received June $21^{\text {st }}, 2013$; revised July $21^{\text {st }}, 2013$; accepted July $29^{\text {th }}, 2013$

Copyright (C) 2013 Kamala Haripal, Sunanda Sahoo. This is an open access article distributed under the Creative Commons Attribution License, which permits unrestricted use, distribution, and reproduction in any medium, provided the original work is properly cited.

\begin{abstract}
Conversion of forest to agricultural fields has become a common practice in India. Very often these fields have been abandoned due to lack of sustainable production. In course of time these fallow lands undergo natural secondary succession. The present study was carried out to find out the restoration of soil physicochemical and biochemical properties in a chronosequence of $2 \mathrm{yr}, 4 \mathrm{yr}, 6 \mathrm{yr}, 11 \mathrm{yr}$, and $15 \mathrm{yr}$ fallow lands. Soil enzyme activities play key roles in the biochemical functioning of soils, including soil organic matter formation and degradation, nutrient cycling, and reflect the change in soil management and land use. There was gradual improvement in the physical condition and nutrient status along with increase in soil amylase, cellulase, dehydrogenase, phophatase, and urease activity in the present study with the progress of fallow age which indicates the importance of natural secondary succession in soil restoration. However the PCA analysis indicated that natural vegetational succession could reclaim the soil quality and promote ecosystem restoration but it required a long time under the present local climatic condition.
\end{abstract}

Keywords: Sustainable Production; Secondary Succession; Soil Restoration; Land Use

\section{Introduction}

India has 329 million ha of total land area of which $43 \%$ is under cropping and $23 \%$ is under forest [1]. From the beginning human has exploited the natural resources for agricultural activities. As a result most of the forests have been converted into agricultural lands. Over recent years there have been intensive agricultural practice basically aimed to enhance the productivity to meet the food demands of huge population throughout the world. In spite of increased population, the productive potential has been decreased in many areas of tropical countries. Intensive cultivation leads to reduced soil fertility and increased soil erosion in many areas of tropics [2]. Specific detrimental effects on biological and biochemical characters of soil quality have also been noted due to changes in microclimate at the soil surface by tillage and on the rate and quality of organic matter input to the soil. Therefore, most of the agro-ecosystems are often abandoned due to unsustainable agricultural production. Maintenance of sustainable agricultural production has become a matter of great concern for the scientists all over the world. In many instances, the disturbed areas undergo natural re- covery of vegetation within 5 to 20 years depending on population pressure and land availability [3].

Soil enzymes (microbial exoenzyme) are recognized as sensitive indicators of soil health and quality [4] due to the rapid response to changes in soil management. In particular, enzyme activities are especially significant in soil quality assessments because of their major contribution to degrading organic matter [5]. In fact they have been related to soil physico-chemical characters, microbial community structure and disturbance [6]. It has been reported that any change in soil management and land use is reflected in the soil enzyme activities, and that they can anticipate changes in soil quality before they are detected by other soil analyses [7]. The studies of soils from different regions indicated that enzyme activities are sensitive to soil changes due to tillage [8], cropping systems [9], and land use [10]. Most of the studies on soil enzyme activities in different land use systems have focused on temperate regions. Few literatures are available regarding the enzyme activities due to land use changes in tropics $[11,12]$.

The present study of enzyme activity in soil along a chronosequence of vegetation regrowth in the fallow 
lands can give insight into the role of soil enzymes in restoring soil fertility during secondary succession. Currently, no information is available on microbial biomass and enzyme activity that affected by conversion of forest into agricultural land, and then into fallow land in India except the work done by Maithani et al. [3] on microbial biomass in 7,13 , and 16 year regrowth of a disturbed subtropical humid forest in Meghalaya, India, and by Ralte et al. [13] on microbial biomass and activity in relation to shifting cultivation and horticultural practices in subtropical evergreen forest ecosystem of North-East India. Thus the present investigation was aimed to assess some key enzyme activities along with some of the selected physico-chemical characters involved in soil restoration in a chronosequence of abandoned rice fields in Western Odisha, India.

\section{Materials and Methods}

\subsection{Study Sites and Climate}

The present study was confined to the revenue district Sambalpur, located in the Western part of Odisha in India. Prior to 1950 s the study sites were dense forest forming a part of Barapahar forest range. After the establishment of multipurpose hydroelectric Hirakud Dam project and subsequent industrialization, urbanization and increase in population pressure, the district forest coverage has been reduced to $30 \%$ [14]. Most of the forest lands were cleared and used for production of agricultural crops (rice, maize, beans and sugarcane). The climate is tropical monsoonal. The annual average rainfall during the study period (August, 2010-July 2011) was $1597 \mathrm{~mm}$ out of which about $80 \%$ fell during rainy season (July-October). The mean air temperature varied from $5^{\circ} \mathrm{C}$ (during December) to $44^{\circ} \mathrm{C}$ (during May). The soils of this district belong to mixed red and black soil, Red sandy soil, mixed red and yellow lateritic soil [15]. The climatological data during the study period are shown in Figure 1. In many places of the study area the rice fields were derived by clearing natural forest which had been subjected to abandonment by farmers due to lack satisfactory agricultural production. All the sampling sites were located on the same topographic situation and with the area of nearly 900 sq meters except 11 yr fallow land which covered 12000 sq meters. The age of the fallow period was ascertained by asking the land owners. By interviewing the elderly persons of the locality it was known that the peoples of these localities were practicing rain fed paddy cultivation since 1975 . The selected study sites were paddy fields abandoned since 1995 (15 yr·F), 1999 (11 yr·F), 2004 (6 yr·F), 2006 (4 $\mathrm{yr} \cdot \mathrm{F})$, and since 2008 ( $2 \mathrm{yr} \cdot \mathrm{F})$.

The 4-year-old field was adjacent to the 6-year-old field, while the 11-year-old field was adjacent to the

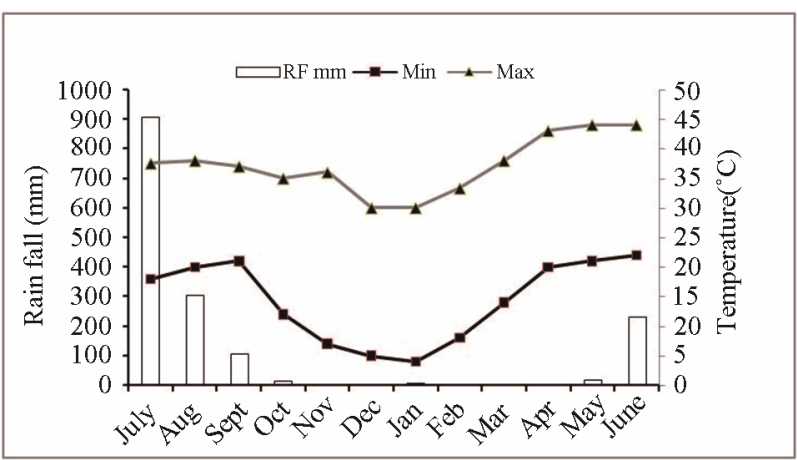

Figure 1. Climate pattern of study sites.

15-year-old field. All these sites were located at the bottom of hill, Chandili Dunguri, 1/2 Km towards south west from Sambalpur University campus at Burla $\left(20^{\circ} 43^{\prime} \mathrm{N}-20^{\circ} 11^{\prime} \mathrm{N}\right.$ and $82^{\circ} 39^{\prime} \mathrm{E}-85^{\circ} 13^{\prime} \mathrm{E}$ longitude, latitude at $263 \mathrm{~m}$ above mean sea level) in Sambalpur district of Odisha, India.

\subsection{Soil Physicochemical Analysis}

The soils were sampled from the experimental plots bimonthly during August 2010- June 2011. The soil samples were taken by using a cylindrical soil sampler having a diameter of $20 \mathrm{~cm}$. and five random samples were taken from $0-10 \mathrm{~cm}, 10-20 \mathrm{~cm}$, and $20-30 \mathrm{~cm}$ depths. The soil samples were packed in plastic zipper bag and brought into the laboratory and stored at $4^{\circ} \mathrm{C}$ before analysis. The enzyme analyses were made within four weeks after sampling because storage beyond two weeks can cause decline in enzyme activities [16]. The soil samples were air dried, gently crushed and sieved through $2 \mathrm{~mm}$ sieve and then used for different physicochemical analysis.

The laboratory analyses were conducted for bulk density and water holding capacity following the method prescribed in TSBF hand book [17], soil $\mathrm{pH}$ by $\mathrm{pH}$ meter using 1:5 soil water suspension, the organic carbon content by Walkely and Black's titration method [18], total nitrogen (TN) by Kjeldhal method [19], the total phosphorus by Bray and Kurtz [20] .Soil microbial biomass carbon was calculated by chloroform fumigation-extraction method [21].

\subsection{Soil Enzyme Activity}

Soil amylase \& cellulase activity was determined following Mishra et al. [22]. $3 \mathrm{~g}$ of soil sample was incubated with $0.2 \mathrm{ml}$ tolune, $6 \mathrm{ml}$ substrate solution (starch for amylase and carboxymethyl cellulose for cellulase) and $6 \mathrm{ml}$ Sorenson's buffer $(\mathrm{pH}=5.9)$ for $24 \mathrm{hr}$ at $34^{\circ} \mathrm{C}$. After incubation the reducing sugar test was performed by adding $2 \mathrm{ml}$ of 3, 5 dinitrosalicylic acid to $1 \mathrm{ml}$ of supernatant of incubated mixture in a test tube and allowed to stand for 5 minutes for colour development. 
The enzyme activity was quantified by spectrophotometer at $540 \mathrm{~nm}$ and expressed in $\mu \mathrm{g}$ glucose $\mathrm{g}^{-1}$ dry soil $\mathrm{hr}^{-1}$.

Soil dehydrogenase was measured according to Casida et al. [23]. $5 \mathrm{~g}$ of soil was incubated with $2 \mathrm{ml}$ of $1 \%$ soluble 2, 3, 5-triphenyl tetrazolium chloride (TTC) in a sealed screw cap test tube at $32^{\circ} \mathrm{C}$ for $24 \mathrm{hr}$. The triphenyl formazon (TPF) formed in the incubated sample was extracted by methanol. The extrantant triphenyl formazon (TPF) was determined by spectrophotometer at $485 \mathrm{~nm}$, using methanol as control.

Acid phosphatase was estimated following the method of Tabatabai and Bremnar [24] using paranitrophenyl phosphate (p-NPP) as a substrate. A mixture of $1 \mathrm{~g}$ fresh soil ( $<2 \mathrm{~mm}), 4 \mathrm{ml}$ of modified universal buffer $(\mathrm{pH} 6.5)$ and $1 \mathrm{ml}$ of $100 \mathrm{mM}$-NPP were incubated in a sealed $100 \mathrm{ml}$ Erlenmeyer flask at $30^{\circ} \mathrm{C}$ for $30 \mathrm{~min}$. The sample was adjusted to $100 \mathrm{ml}$ with deionised water. After incubation the para- nitrophenol (p-NP) was filtered through Whatman-42 and quantified by spectrophotometer at 400 $\mathrm{nm}$ by taking $\mathrm{p}-\mathrm{NP}$ as control.

Urease activity was determined as described by Dash et al. [25]. $0.2 \mathrm{ml}$ toluene was added to $5 \mathrm{~g}$ soil and $9 \mathrm{ml}$ of Tris- $\mathrm{HCl}$ buffer $(\mathrm{pH}=9,0.2 \mathrm{M})$ followed by $1 \mathrm{ml}$ of $0.2 \mathrm{M}$ urea (substrate solution) to the sample. The sam- ples were subsequently incubated at $37^{\circ} \mathrm{C}$ for $2 \mathrm{hrs}$. After incubation the volume was made up to the mark $(50 \mathrm{ml})$ by adding $\mathrm{KCl}-\mathrm{AgSO}_{4}$. The suspension was centrifuged. To $1 \mathrm{ml}$ of supernatant, $1 \mathrm{ml}$ of phenol and $1 \mathrm{ml}$ of alkaline hypo chlorite solution were added. After $5 \mathrm{~min}$, the released ammonium was measured spectrophotometrically at $625 \mathrm{~nm}$.

\subsection{Statistical Analysis}

The data were statically analyzed using three way analysis of variance (ANOVA) with SPSS 10 statistical software. Pearson's correlation analysis was performed to determine the significant level of correlation. The PCA was done using SX software to discriminate different sites on the basis of the principal components $Z_{1}$ and $Z_{2}$.

\section{Results}

\subsection{Soil Physico-Chemical Properties}

Soil physico-chemical properties of the present study sites have been presented in Table 1. Soil moisture content increased gradually along the chronosequence of abandoned field (Table 1). ANOVA revealed a significant impact of fallow period on soil moisture content.

Table 1. Soil physico-chemical properties of different abandoned fields at different depths.

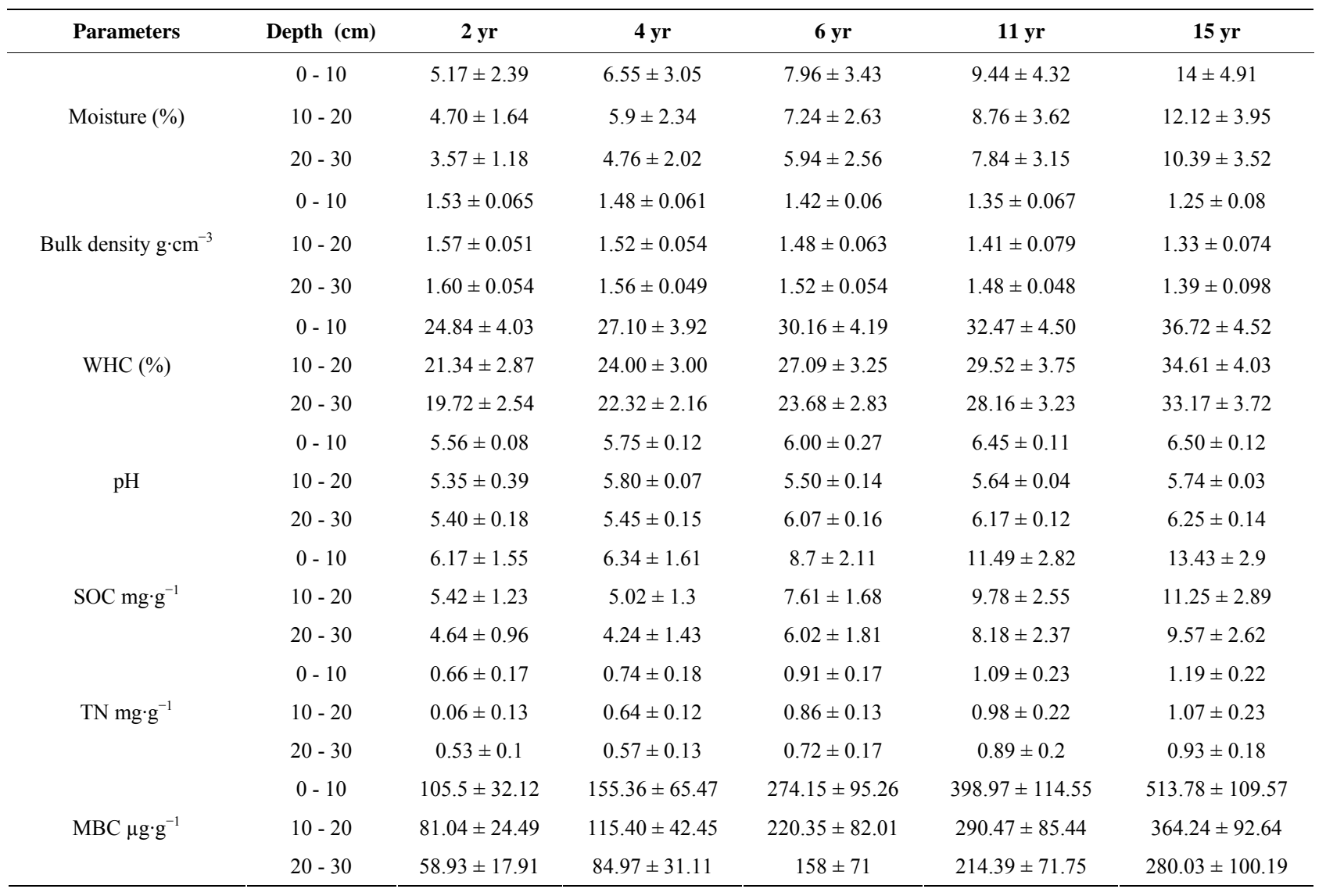



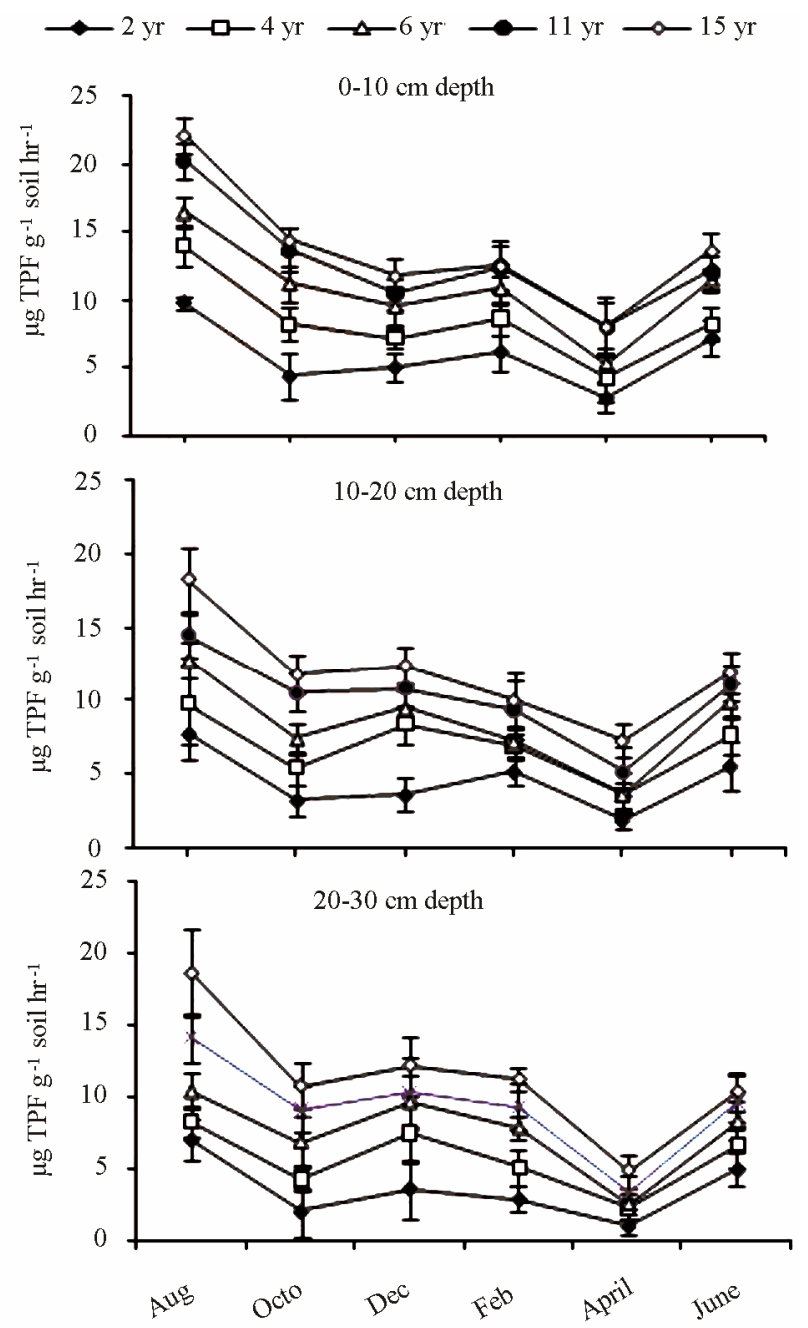

Figure 2. Amylase activity in soil of different abandoned fields during different months and at different depths.

Decreasing level of soil moisture was found with increase in depth irrespective of fallow period. The bulk density ranged from $1.25 \mathrm{~g} \cdot \mathrm{cm}^{-3}$ in the surface soil layer $(0-10 \mathrm{~cm})$ of $15 \mathrm{yr} \cdot \mathrm{F}$ land to $1.6 \mathrm{~g} \cdot \mathrm{cm}^{-3}$ in the subsurface layer $(20-30 \mathrm{~cm})$ of $2 \mathrm{yr} \cdot \mathrm{F}$ land. Lowest water holding capacity (WHC) was recorded at $20-30 \mathrm{~cm}$ depth of $2 \mathrm{yr}$ abandoned field (19.72\%) and highest WHC was recorded in $0-10 \mathrm{~cm}$ depth of $15 \mathrm{yr}$ abandoned field $(36.7 \%)$. ANOVA revealed significant difference of WHC between different fallow lands and between depths at $\mathrm{p}<0.001$.

The soil $\mathrm{pH}$ was acidic in nature and varied from 5.35 to 6.28. The $\mathrm{pH}$ value increased over time since abandonment and highest value was seen in the upper soil layer $(0-10 \mathrm{~cm})$ of $15 \mathrm{yr} \cdot \mathrm{F}$ land. The soil organic matter increased significantly with increasing year of abandonment being highest in $0-10 \mathrm{~cm}$ depth of $15 \mathrm{yr}$ abandoned field ( $\left.13.43 \mathrm{mg} \cdot \mathrm{g}^{-1}\right)$ and lowest in $20-30 \mathrm{~cm}$ depth of $2 \mathrm{yr} \cdot \mathrm{F}$ lands $\left(6.17 \mathrm{mg} \cdot \mathrm{g}^{-1}\right)$. Similar trend was

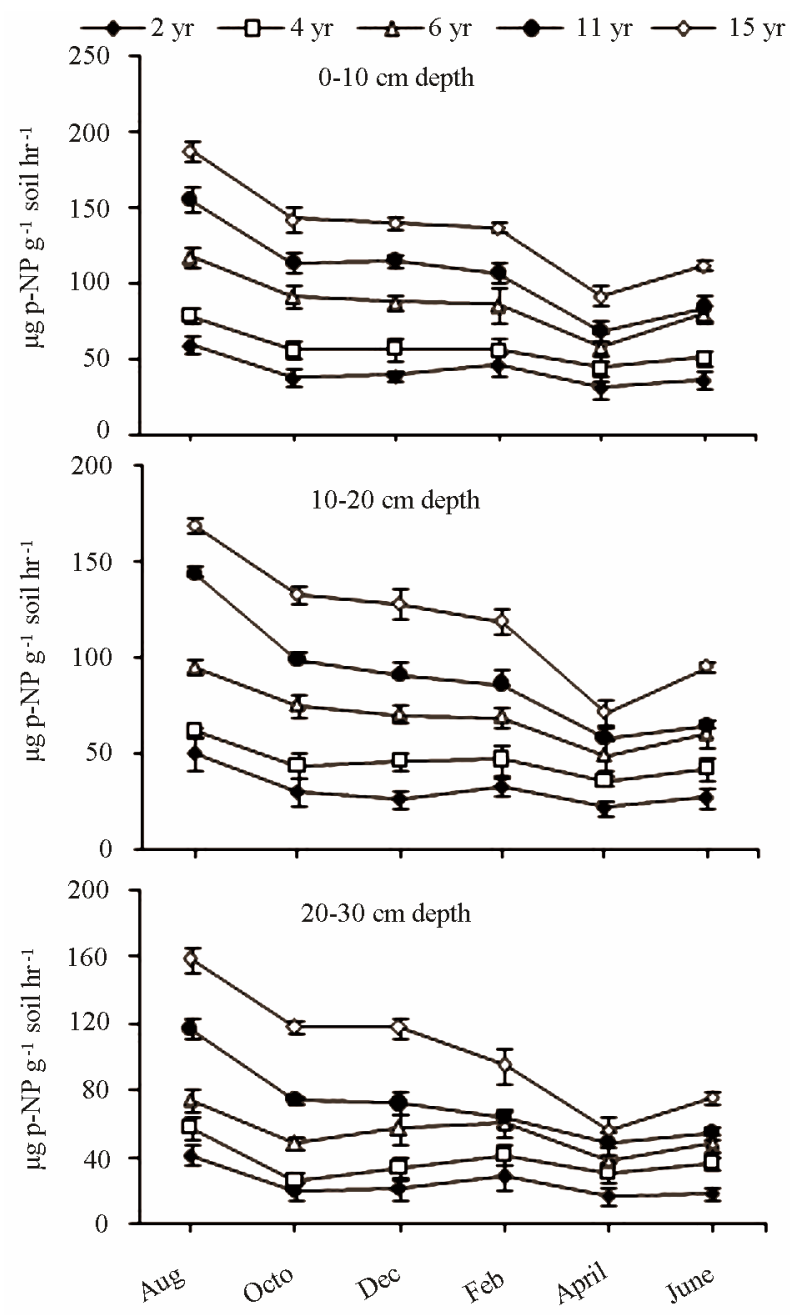

Figure 3. Cellulase activity in soil of different abandoned fields during different months and at different depths.

observed for total nitrogen in the soil. The Soil microbial biomass carbon ranged from 104.50 to $513 \mu \mathrm{g} \cdot \mathrm{g}^{-1}$ in top soil $(0-10 \mathrm{~cm}), 81.04$ to $364 \mu \mathrm{g} \cdot \mathrm{g}^{-1}$ of soil in $20-30 \mathrm{~cm}$ depth and 58.93 to $280 \mu \mathrm{g} \cdot \mathrm{g}^{-1}$ in $20-30 \mathrm{~cm}$ soil depth.

\subsection{Soil Enzyme Activity}

Figures 2-6 show amylase, cellulase, dehydrogenase, phosphatase and urease activities respectively in relation to sites, depth and season. Highest activities of all the enzymes were observed in top soil $(0-10 \mathrm{~cm})$, and were found to be decreasing with increasing depths. Seasonal variations in the enzyme activities in different sites indicated a peak during August (wet season) and lowest enzyme activities was observed in dry season i.e. during April. All the enzyme activities increased with the increase in years of abandonment. ANOVA revealed significant difference between sites, depths, and between different seasons at $\mathrm{p}<0.001$. Pearson's correlation analysis indicated significant correlation between en- 

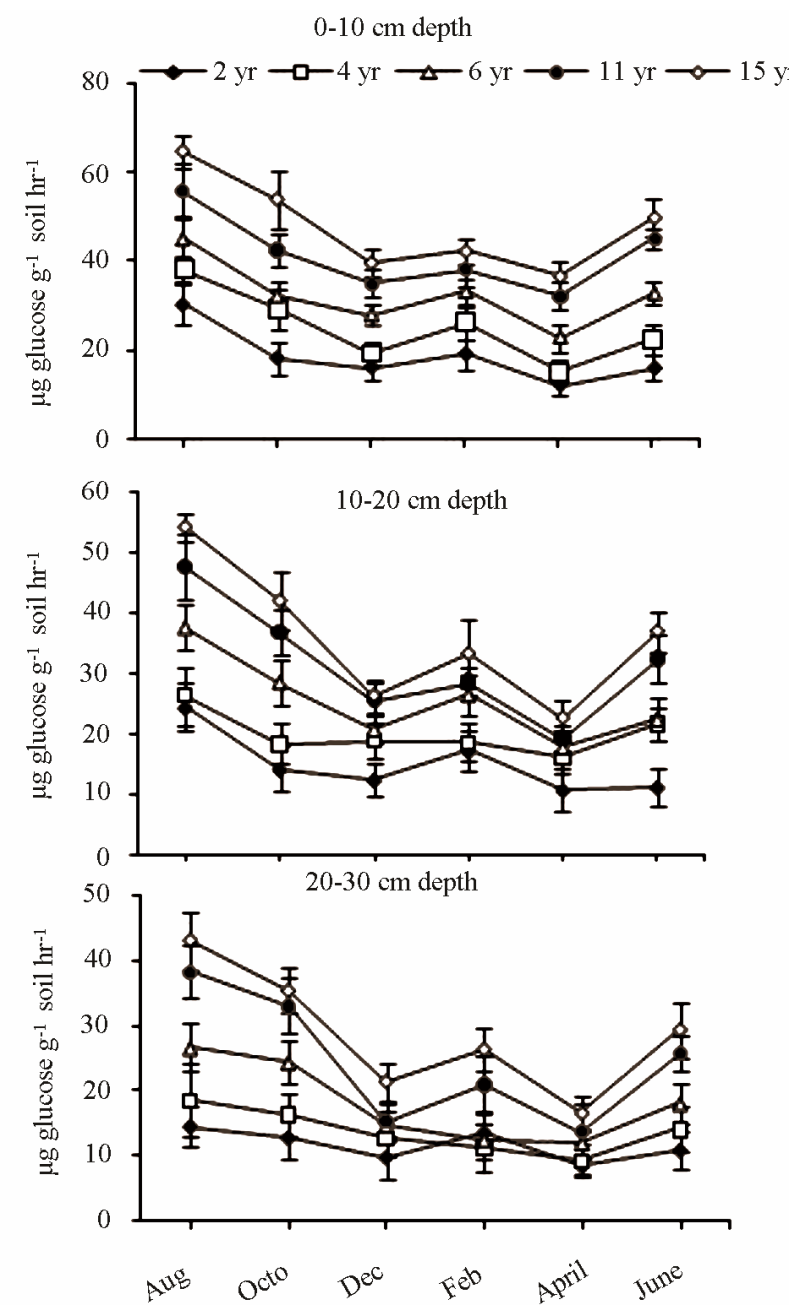

Figure 4. Dehydrogenase activity in soil of different abandoned fields during different months and at different depths.

zyme activities and soil physico-chemical parameters (Table 2).

\section{Discussion}

\subsection{Soil Physico-Chemical Properties}

In the present study, soil was slightly acidic ranging from 5.58 to 6.58 . Leaching process tends to acidify soils and partially offset by plant growth [26]. Gradual establishment of plants with increasing year of abandonment is supposed to prevent much of the leaching in WHC and decrease the bulk density. As the fallow period gets extended, the inputs of organic residues from colonizing plants increased the carbon and nitrogen contents of soil. During the natural restoration in 3, 7, 10 year abandoned paddy fields an increase in pools of organic matter, total nitrogen, exchangeable $\mathrm{K}, \mathrm{Ca}, \mathrm{Mg}$ and $\mathrm{pH}$ was observed with increase of field age [27]. This supports the present findings. Microbial biomass

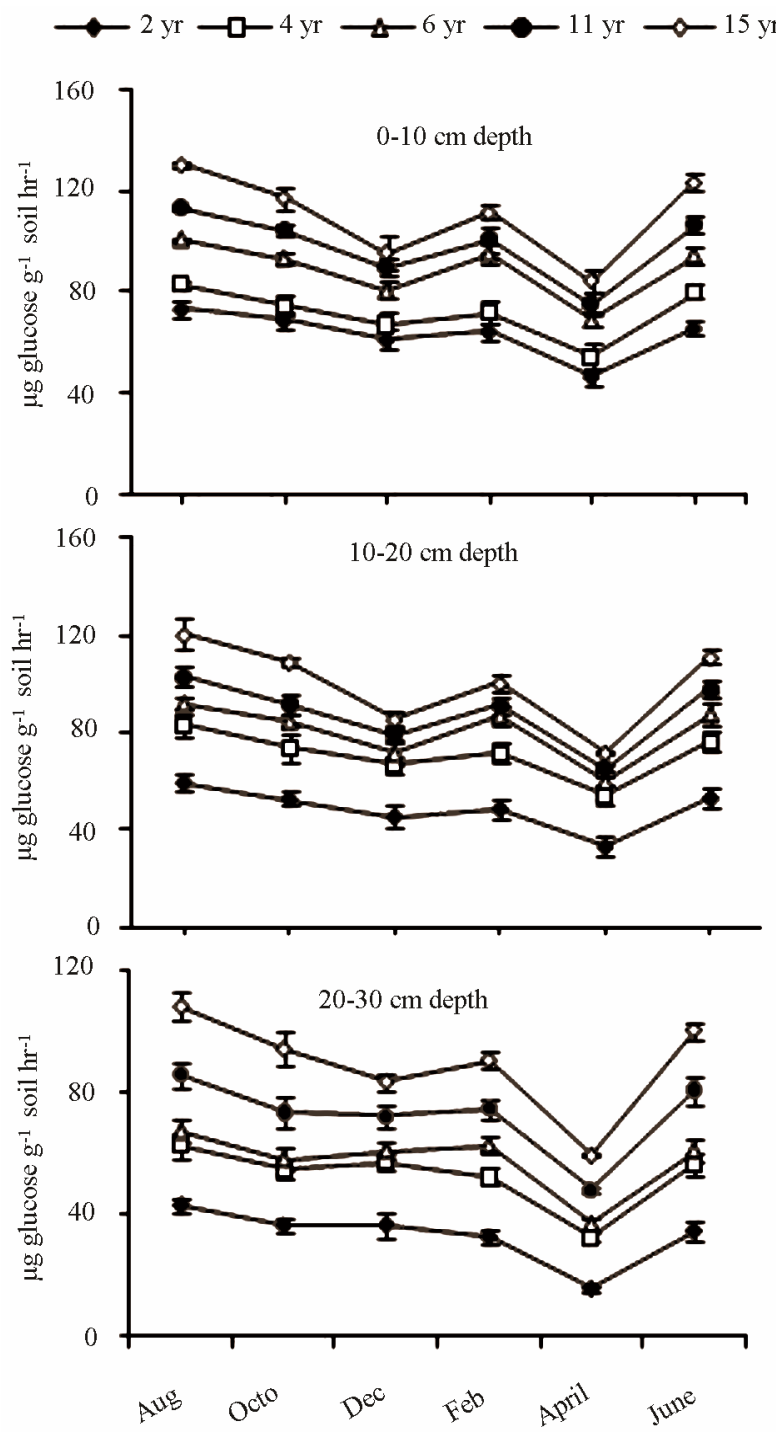

Figure 5. Phosphatase activity in soil of different abandoned fields during different months and at different depths.

reflects the degree of immobilization of $\mathrm{C}$ and $\mathrm{N}$ in soil. Gradual increase in microbial biomass carbon (MBC) was recorded in the present study with a maximum amount in the top soil of $15 \mathrm{yr} \cdot \mathrm{F}$ land $\left(513.78 \mu \mathrm{g} \cdot \mathrm{g}^{-1}\right)$.

This may be attributed to greater input of plant detritus that is ultimately incorporated into the soil and improves the nutrient pool thereby increases the MBC [28]. The MBC dynamic was significantly correlated with soil organic carbon content during the secondary succession as reported by Arunachalam and Pandey [29]. The present study supports the above findings. This result indicated that organic matter played a pivotal role in the building up and development of soil microbial biomass [30].

\subsection{Soil Enzyme Activity}

Soils enzymes are major indicators of microbial activity, 
Table 2. Pearson's Correlation coefficients between soil properties.

\begin{tabular}{|c|c|c|c|c|c|c|c|c|c|c|c|c|}
\hline & SM & WHC & BD & $\mathrm{pH}$ & $\mathrm{OC}$ & $\mathrm{MBC}$ & $\mathrm{TN}$ & AML & CEL & DEH & PHO & URE \\
\hline SM & 1 & & & & & & & & & & & \\
\hline WHC & $0.45^{* *}$ & 1 & & & & & & & & & & \\
\hline $\mathrm{BD}$ & $-0.34^{* *}$ & $-0.71^{* *}$ & 1 & & & & & & & & & \\
\hline $\mathrm{pH}$ & $0.41^{* *}$ & $0.54^{* *}$ & $-0.51^{* *}$ & 1 & & & & & & & & \\
\hline $\mathrm{OC}$ & $0.85^{* *}$ & $0.56^{* *}$ & $-0.51^{* *}$ & $0.51^{* *}$ & 1 & & & & & & & \\
\hline MBC & $0.85^{* *}$ & $0.6^{* *}$ & $-0.54^{* *}$ & $0.61^{* *}$ & $0.90^{* *}$ & 1 & & & & & & \\
\hline $\mathrm{TN}$ & $0.86^{* *}$ & $0.55^{* *}$ & $-0.47^{* *}$ & $0.49^{* *}$ & $0.97^{* *}$ & $0.89^{* *}$ & 1 & & & & & \\
\hline AML & $0.86^{* *}$ & $0.55^{* *}$ & $-0.47^{* *}$ & $0.51^{* *}$ & $0.86^{* *}$ & $0.88^{* *}$ & $0.85^{* *}$ & 1 & & & & \\
\hline CEL & $0.83^{* *}$ & $0.59^{* *}$ & $-0.6^{* *}$ & $0.48^{* *}$ & $0.81^{* *}$ & $0.83^{* *}$ & $0.81^{* *}$ & $0.89^{* *}$ & 1 & & & \\
\hline DEH & $0.82^{* *}$ & $0.54^{* *}$ & $-0.44^{* *}$ & $0.4^{* *}$ & $0.81^{* *}$ & $0.76^{* *}$ & $0.81^{* *}$ & $0.86^{* *}$ & $0.86^{* *}$ & 1 & & \\
\hline PHO & $0.85^{* *}$ & $0.64^{* *}$ & $-0.59^{* *}$ & $0.53^{* *}$ & $0.92^{* *}$ & $0.88^{* *}$ & $0.91^{* *}$ & $0.87^{* *}$ & $0.86^{* *}$ & $0.87^{* *}$ & 1 & \\
\hline URE & $0.89^{* *}$ & $0.57^{* *}$ & $-0.52^{* *}$ & $0.49^{* *}$ & $0.85^{* *}$ & $0.88^{* *}$ & $0.84^{* *}$ & $0.92^{* *}$ & $0.93^{* *}$ & $0.87^{* *}$ & $0.89^{* *}$ & 1 \\
\hline
\end{tabular}

${ }^{* *}$ Significant at $\mathrm{p}<0.01 ;{ }^{\mathrm{SM}}$ Soil moisture, ${ }^{\mathrm{WHC}}$ Water holding capacity, ${ }^{\mathrm{BD}}$ Bulk density, ${ }^{\mathrm{OC}}$ Organic carbon, ${ }^{\mathrm{TN}}$ Total nitrogen, ${ }^{\mathrm{AML}}$ Amylase activity, ${ }^{\mathrm{CEL}}$ Cellulase activity, ${ }^{\mathrm{DEH}}$ Dehydrogenase activity, ${ }^{\mathrm{PHO}}$ Phosphatase activity, ${ }^{\mathrm{UR}}$ Urease activity.

and their activities always depend upon soil types, vegetation cover, microbial biomass, and microbial diversity during vegetation succession [31]. Dehydrogenase is an intracellular enzyme that exists only in viable microbial cells and it is considered as an index of microbial activity [32]. In the present study the enzyme activities showed peak value in rainy season (August) and lowest in summer (April). Some hydrolases have a tendency to increase in the rainy season [33]. During summer, due to moisture stress, the microbes are in dormant state and their activities become low, but the entry of rainy season caused spurt in flora and microbial population, and thus increased the enzyme activities. Prolonged precipitation along with enhanced plant growth and rhizoid position result in increased extracellular activities [34,35]. The activity of dehydrogenase, phosphatase and urease was found to decrease in summer [36]. Thus the present finding is in agreement with the above observations.

There was significant increase in extracellular enzymes like amylase, cellulase, phosphatase, urease, and intracellular enzyme i.e. dehydrogenase with increasing year of fallow period and significant decrease with increase in soil depth. Significantly positive correlation was found between all the enzyme activities with organic carbon, total nitrogen and microbial biomass carbon (Table 2). Increasing age of the land with respect to time caused gradual addition of organic matter to the soil through decomposition of shoot and root biomass of different vegetation developed on the surface layer. Higher organic matter content provides higher substrate which acts as energy source for microorganisms and supports high amount of microorganism, hence higher enzyme activities [30]. Later succession exhibited higher enzyme activity than the early period and upper soil layer showed higher enzyme activity than lower layer of soil. The decrease in these enzyme activities with depth might be attributed to the diminution of biological activity down the soil profile [37].

The data on physico-chemical parameters and enzyme activities of present study and the data of natural forest, natural grassland and crop field obtained in the same topography [38] were subjected to principal component analysis. Figure 7 illustrates the discrimination of different sites on the basis of $Z_{1}$ and $Z_{2}$ whose cumulative percent variance was $85.9 \%$. The PC separated the $2 \mathrm{yr}$, $4 \mathrm{yr}$, $6 \mathrm{yr}, 11 \mathrm{yr}, 15 \mathrm{yr}$ fallow far away from grassland and crop fields. However the $15 \mathrm{yr} \mathrm{F}$ is quite nearer to natural forest which indicates that the chronosequence of abandoned fields showed a general trend of reclamation in terms of some of the soil Physico-chemical and biochemical parameters but still required more time to achieve the soil status of natural forest, crop fields, and grasslands. Self regeneration of vegetation on a degraded land in tropics has relatively better reclamation potential 


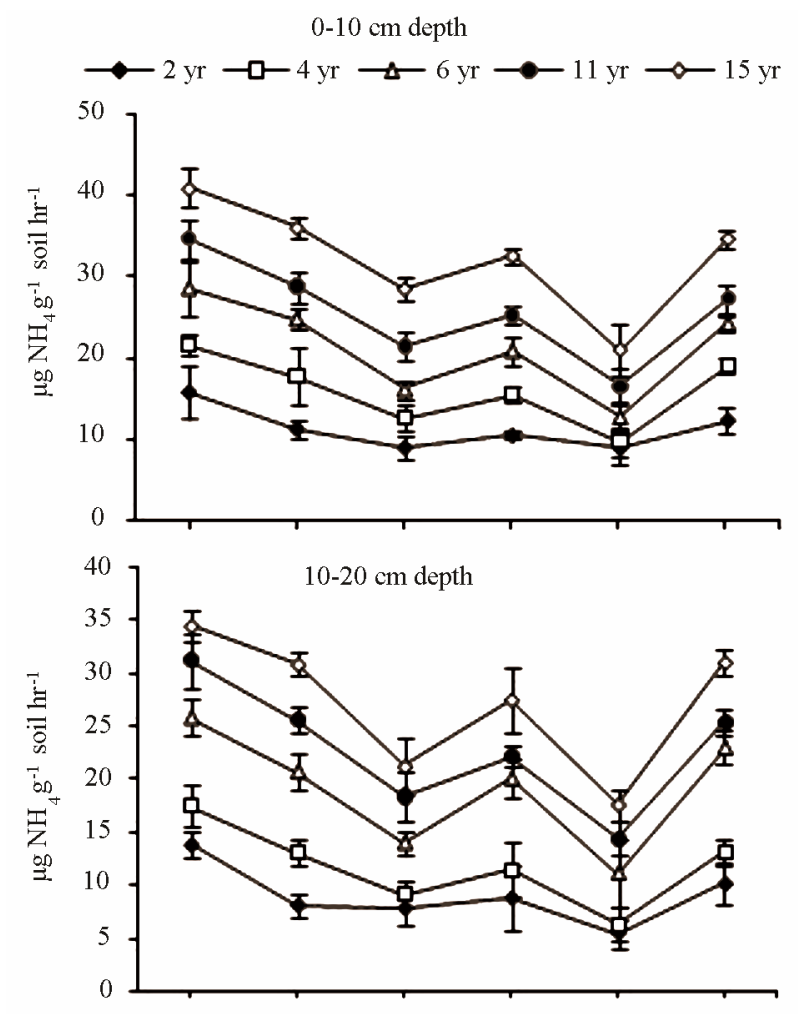

than that of plantation species [39]. Thus the study justified that the degraded ecosystems derived from natural forest when subjected to abandonment showed the symptoms of reclamation during the course of natural seconddary succession.

\section{Acknowledgements}

The authors are grateful to Prof N. Behera, Head, School of Life Sciences, Sambalpur University for providing necessary facilities to carry out the present work. Also the authors are thankful to Dr. S K Pattanayak, P G Department of Environmental Science, Sambalpur University for some of his important suggestions and comments during the preparation of the manuscript.

\section{REFERENCES}

[1] Ministry of Environment and Forests, "Annual Report," Ministry of Environment and Forest, Government of India, New Delhi, 1999.

[2] N. Sanginga, F. Zapata, S. K. A. Danso and G. D. Bowen, "Estimating Nitrogen Fixation in Leucaena and Gliricidia Using Different ${ }^{15} \mathrm{~N}$ Labelling Methods," In: K. Mulongoy, M. Gueye and D. C. Spencer, Eds., Biological Nitrogen Fixation and Sustainability of Tropical Agriculture, IITA, Wiley-Sayce and AABNF Co-Publication, Chichester, New York, Grisbane, Toronto and Singapore, 1992, pp. 265-275.

[3] K. Maithani, R. S. Tripathi, A. Arunachalam and H. N. Pandey, "Seasonal Dynamics of Microbial Biomass C, N and P during Regrowth of a Subtropical Humid Forest in North-East India," Applied Soil Ecology, Vol. 4, No. 1, 1996, pp. 31-37. doi:10.1016/0929-1393(96)00101-1

[4] B. A. Caldwell, "Enzyme Activities as a Component of Soil Biodiversity: A Review," Pedobiologia, Vol. 49, No. 6, 2005, pp. 637-644. doi:10.1016/i.pedobi.2005.06.003

[5] M. Scholter, O. Dilly and J. C. Munch, "Indicators for Evaluating Soil Quality," Agriculture, Ecosystems \& Environment, Vol. 98, No. 1-3, 2003, pp. 255-262. doi:10.1016/S0167-8809(03)00085-9

Figure 6. Urease activity in soil of different abandoned fields during different months and at different depths.

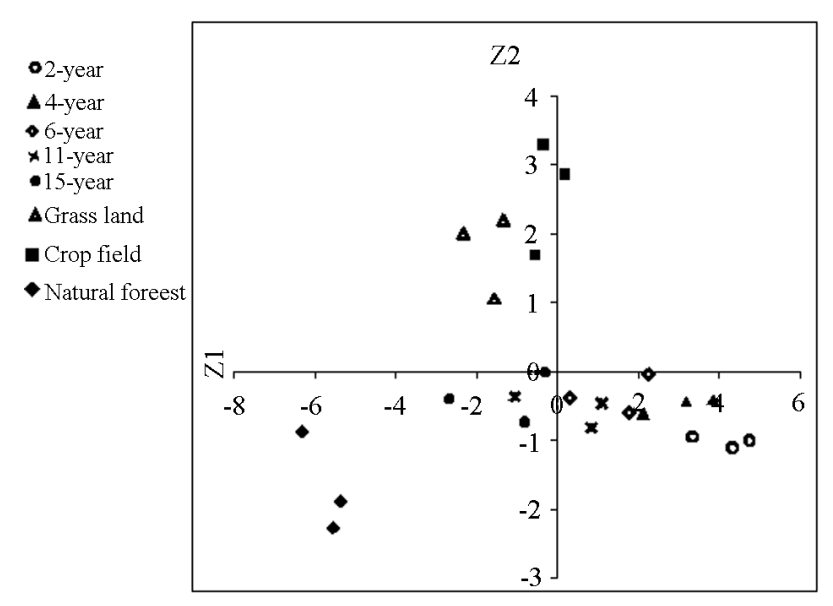

Figure 7. PCA analysis of different study sites.
[6] R. E. J. Boerner, K. L. M. Decker and E. K. Sutherland, "Prescribed Burning Effects on Soil Enzyme Activity in a Southern Ohio Hardwood Forest: A Landscape-Scale Analysis," Soil Biology \& Biochemistry, Vol. 32, No. 7, 2000, pp. 899-908. doi:10.1016/S0038-0717(99)00208-4

[7] E. I. Ndiaye, J. M. Sandeno, D. McGrath and R. P. Dick, "Integrative Biological Indicators for Detecting Change In Soil Quality," American journal of Alternative Agriculture, Vol. 15, No. 1, 2000, pp. 26-36. doi: $10.1017 / \mathrm{S} 0889189300008432$

[8] V. Acosta-Martinez and M. A. Tabatabai, "Enzyme Activities of a Lime Agricultural Soil," Biology and Fertility of Soil, Vol. 31, No. 1, 2001, pp. 85-91. doi:10.1007/s003740050628

[9] M. Ekenler and M. A. Tabatabai, " $\beta$-Glucosaminidase Activity of Soils: Effect of Cropping Systems and Its Re- 
lationship to Nitrogen Mineralization," Biology and Fertility of Soils, Vol. 36, No. 5, 2002, pp. 367-376. doi:10.1007/s00374-002-0541-x

[10] V. Acosta-Martinez, L. Cruz, D. Sotomayor-Ramirez and L. Perez-Alegria, "Enzyme Activities as Affected by Soil Properties and Land Use in a Tropical Watershed," Applied Soil Ecology, Vol. 35, No. 1, 2007, pp. 35-45. doi:10.1016/j.apsoil.2006.05.012

[11] V. Acosta-Martinez, D. Acosta-Mercado, D. SotomayorRamirez and L. Cruz-Rodriguez, "Microbial Communities Activities under Different Activities under Different Management in Semi-Arid Soils," Applied Soil Ecology, Vol. 38, No. 3, 2008, pp. 249-260. doi:10.1016/j.apsoil.2007.10.012

[12] R. Kizilkaya and O. Dengiz, "Variation of Land Use and Land Cover Effects on Some Soil Physic-Chemical Characteristics and Soil Enzyme Activity," Zemdirbyste-Agriculture, Vol. 97, No. 2, 2010, pp. 15-24.

[13] V. Ralte, H. N. Pandey, S. K. Barik, R. S. Tripathy and S. D. Prabhu, "Changes in Microbial Biomass and Activity in Relation to Shifting Cultivation and Horticultural Practices in Sub-Tropical Ever Green Forest Ecosystem of North East India," Acta Oecologica, Vol. 28, 2005, pp. 163-172. doi:10.1016/j.actao.2005.04.001

[14] S. K. Joshi, "Production and Decomposition of Litter in a Tropical Mixed Wood Forest from Orissa, India," Ph.D. Thesis, Sambalpur University, Orissa, 1990.

[15] K. L. Mohanty, "Agricultural Guide Book," Goswami Press, Orissa, 1971.

[16] L. T. Benjamin and E. R. Tania, "Stability of Hydrolytic Enzyme Activity and Microbial Phosphorus during Storage of Tropical Rain Forest Soils," Soil Biology \& Biochemistry, Vol. 42, No. 3, 2010, pp. 459-465. doi:10.1016/j.soilbio.2009.11.029

[17] J. M. Anderson and J. S. I. Ingram, "Tropical Soil Biology and Fertility: A Hand Book of Methods," 2nd Edition, CAB International, Wallingford, 1993.

[18] A. Walkley and I. A. Black, "An Examination of the Degtjareff Method for Determining Organicmatter and A Proposed Modification of the Chromic Acid Titration Method," Soil Science, Vol. 37, No. 1, 1934, pp. 251-263. doi:10.1097/00010694-193401000-00003

[19] M. L. Jackson, "Soil Chemical Analysis," Prentice-Hall: Englewood Cliffs, 1958.

[20] R. H. Brady and L. T. Kurtz, "Determination of Total Organic and Available Phosphorous in Soils," Soil Science, Vol. 59, No. 1, 1945, pp. 39-45. doi:10.1097/00010694-194501000-00006

[21] E. D. Vance, P. C. Brookes and D. S. Jenkinson, “An Extraction Method for Measuring Soil Microbial Biomass C," Soil Biology \& Biochemistry, Vol. 19, No. 6, 1987, pp. 703-707. doi:10.1016/0038-0717(87)90052-6

[22] P. C. Mishra, R. K. Mohanty and M. C. Dash, "Enzyme Activities in Subtropical Surface Soils under Pasture," Indian Journal of Agricultural Chemistry, Vol. 12, No. 1, 1979, pp. 19-24.

[23] L. E. Casida Jr., D. A. Klein and D. Sntoro, "Soil Dehydrogenase Activity," Soil Science, Vol. 98, No. 6, 1964, pp. 371-378. doi:10.1097/00010694-196412000-00004

[24] M. A. Tabatabai and J. M. Bremner, "Use of p-Nitrophenyl Phosphatefor Assay of Soil Phosphatase Activity," Soil Biology and Biochemistry, Vol. 4, No. 3, 1969, pp. 301-307. doi:10.1016/0038-0717(69)90012-1

[25] M. C. Dash, P. C. Mishra, R. K. Mohanty and N. Bhattm, "Effects of Specific Conductance and Temperature on Urease Activity in Some Indian Soils," Soil Biology and Bio-Chemistry, Vol. 13, No. 1, 1981, pp. 73-74. doi:10.1016/0038-0717(81)90105-X

[26] F. R. Troeh and L. M. Thompson, "Soils and Fertility," 5th Edition, Oxford University Press Inc., New York, 1993.

[27] C. Lee, Y. You and R. G. Robinson, "Secondary Succesion and Habitat Restoration in Abandoned Rice Fields of Central Korea," Restoration Ecology, Vol. 10, No. 2, 2002, pp. 306-314. doi:10.1046/j.1526-100X.2002.00003.x

[28] K. Maithani, A. Arunachalam and R. S. Tripathy, "Influence of Leaf Litter Quality on N-Miniralization in Soils of Sub-Tropical Humid Forest Regrowths," Biology and Fertility of Soil, Vol. 27, No. 1, 1998. pp. 44-50. doi: $10.1007 / \mathrm{s} 003740050398$

[29] A. Arunachalam and H. N. Pandey, "Ecosystem Restoration of Jhum Fallows in Northeast India: Microbial C and $\mathrm{N}$ along Altitudinal and Successional Gradients," Restoration Ecology, Vol. 11, No. 2, 2003, pp. 1-6. doi:10.1046/j.1526-100X.2003.00013.X

[30] Y. B. Cheng and D.-X. Yue, "Soil Microbial and Enzymatic Activities across a Chronosequence of Chinese Pine Plantation Development on the Loess Plateau of China," Pedosphere, Vol. 22, No. 1, 2012. pp. 1-12. doi:10.1016/S1002-0160(11)60186-0

[31] J. P. Taylor, B. Wilson, M. S. Mills and R. G. Burns, "Comparison of Microbial Numbers and Microbial Activities in Surface Soils and Sub Soils Using Various Techniques," Soil Biology \& Biochemistry, Vol. 34, No. 3, 2002, pp. 387-401. doi:10.1016/S0038-0717(01)00199-7

[32] P. Nannipieri, S. Grego and B. Ceccanti, "Ecological Significance of Biological Activity in Soils," In: J. M. Bollage and G. Stotzky, Eds., Soil Biochemistry, Marcel Dekker, New York, 1990, pp. 293-355.

[33] S. Kramer and D. M. Green, "Acid and Alkaline Phosphatase Dynamics and Their Relationship to Soil Microclimate in a Semiarid Woodland," Soil Biology \& Biochemistry, Vol. 32, No. 2, 2000, pp. 179-188. doi:10.1016/S0038-0717(99)00140-6

[34] T. H. Bell and H. A. I. Henry, "Fine Scale Variability in Soil Extrcellular Enzyme Activity Is Sensitive to Rain Events and Temperature in a Mesic System," Pedobiologia, Vol. 54, No. 2, 2011, pp. 141-146. doi:10.1016/i.pedobi.2010.12.003

[35] H. A. I. Henry, "Soil Extracellular Enzyme Dynamics in a Changing Climate," Soil Biology and Biochemistry, Vol. 47, 2012, pp. 53-59. doi:10.1016/j.soilbio.2011.12.026

[36] J. F. Dormaar, A. Johnston and S. Smoliak, "Seasonal Changes in Carbon Content, and Dehydrogenazs, Phosphatase, and Urease Activities in Mixed Prairie and Fes- 
cue Grassland Ah Horizons," Journal of Range Management, Vol. 37, No. 1, 1984, 31-35. doi:10.2307/3898819

[37] M. Matinizadeh, S. A. A. Korori and W. Praznik, "Enzyme Activities in Undisturbed and Disturbed Forest Soil under Oak (Quercus brantii var. Persica) as Affected by Soil Depth and Seasonal Variation," Asian Journal of Plant Sciences, Vol. 7, No. 4, 2008, pp. 368-374.

doi:10.3923/ajps.2008.368.374
[38] P. Prasad, "Soil Microbial Biomass and Activity in Some Tropical Agroecosystems," Ph.D. Thesis, Sambalpur University, Odisha, 1996.

[39] U. Sahani, "Role of Plantation Forestry in Reclamation of Degraded Tropical Forest," Ph.D. Thesis, Sambalpur University, Odisha, 2002. 